Monika Sri Yuliarti, Andre N. Rahmanto, Anjang Priliantini, Albert Muhammad Isrun Naini, Mahfud Anshori, Christina Tri Hendriyani:

Storytelling of Indonesia Tourism Marketing in Social Media: Study of Borobudur and Danau Toba Instagram Account

Storytelling dalam Pemasaran Pariwisata Indonesia di Media Sosial: Studi Akun Instagram Borobudur dan Danau Toba

\title{
Storytelling of Indonesia Tourism Marketing in Social Media: Study of Borobudur and Danau Toba Instagram Account
}

\section{Storytelling dalam Pemasaran Pariwisata Indonesia di Media Sosial: Studi Akun Instagram Borobudur dan Danau Toba}

\author{
Monika Sri Yuliarti ${ }^{1}$, Andre N. Rahmanto ${ }^{2}$, Anjang Priliantini ${ }^{3}$, Albert Muhammad Isrun Naini ${ }^{4}$, \\ Mahfud Anshori ${ }^{5}$, Christina Tri Hendriyani ${ }^{6}$ \\ ${ }^{1}$ Universitas Sebelas Maret, J1. Ir. Sutami 36A Surakarta, Indonesia* \\ Email: monika.yuliarti@staff.uns.ac.id \\ ${ }^{2}$ Universitas Sebelas Maret, Jl. Ir. Sutami 36A Surakarta, Indonesia \\ Email: andreyuda@gmail.com \\ ${ }^{3}$ Universitas Sebelas Maret, J1. Ir. Sutami 36A Surakarta, Indonesia \\ Email: anjangpriliantini@staff.uns.ac.id \\ ${ }^{4}$ Universitas Sebelas Maret, J1. Ir. Sutami 36A Surakarta, Indonesia \\ Email: albert_muhammad@yahoo.com \\ ${ }^{5}$ Universitas Sebelas Maret, J1. Ir. Sutami 36A Surakarta, Indonesia \\ Email: mahfudanshori fisip@staff.uns.ac.id \\ ${ }^{6}$ Universitas Sebelas Maret, J1. Ir. Sutami 36A Surakarta, Indonesia \\ Email: christinath@staff.uns.ac.id
}

Masuk tanggal : 10-09-2020, revisi tanggal : 04-03-2021, diterima untuk diterbitkan tanggal : 01-04-2021

\begin{abstract}
The effort to improve the number of tourist visits and foreign exchange have been happening in Indonesia. However, in its development, there are several obstacles, one of which is related to promotion. Therefore, it is necessary to implement the concept of storydriven marketing as an effort to promote tourism through stories and impressions that are disseminated through social media, by applying storytelling. This study aims to explore storytelling in two tourist destinations that are part of 5 super priority tourism destinations, Borobudur in Central Java and Danau Toba in South Sumatra, by looking at the Instagram accounts of the two tourist destinations, which are @borobudurpark and @danau_tobasamosir. This quantitative descriptive study used content analysis methods to study 3 elements of tourism in accordance with the 2009 Tourism Law (attractions, amenities, and accessibility), and also 5 elements of storytelling (setting, character, plot, conflict, and message). The research data was collected through document study by studying the Instagramaccount @borobudurparkand @danau_tobasamosir.The findings in this study are that the storytelling strategy is not yet optimal as a story-driven marketing strategy in tourism, because not all elements of storytelling appear in the posts of the research object's Instagram account. Most of the posts on the Instagram account of the Borobudur and Lake Toba tourist destinations only refer to the elements of the message and pay less attention to other elements of storytelling. The implication of this research is the need for various parties involved in tourism development to optimize social media as a means of promotion and improve storytelling strategies to attract tourists.
\end{abstract}

Keywords: Borobudur, Danau Toba, Instagram, storytelling, tourism 


\begin{abstract}
Abstrak
Target jumlah kunjungan wisatawan dan penerimaan devisa Indonesia terus diupayakan peningkatannya dari tahun ke tahun. Namun dalam pengembangannya, ada beberapa kendala yang dihadapi, salah satunya terkait promosi. Karenanya, dirasa perlu mengimplementasi konsep story-driven marketing sebagai upaya promosi wisata melalui cerita dan kesan yang disebarluaskan melalui media sosial, yaitu dengan mengaplikasikan storytelling. Penelitian ini bertujuan untuk mengeksplorasi storytelling dalam dua destinasi wisata yang masuk dalam kategori 5 destinasi super prioritas pariwisata, yaitu Borobudur di Jawa Tengah dan Danau Toba di Sumatera Selatan, dengan melihat akun Instagram kedua destinasi wisata tersebut, yakni. Penelitian deskriptif kuantitatif ini menggunakan metode analisis isi untuk mengkaji 3 unsur pariwisata sesuai UU tentang Kepariwisataan tahun 2009 (atraksi, amenitas, dan aksesibilitas) serta 5 unsur storytelling (setting, karakter, plot, konflik, dan pesan). Data penelitian dikumpulkan melalui studi dokumen dengan mempelajari akun Instagram @ borobudurparkdan @danau_tobasamosir. Temuan dalam penelitian ini adalah belum optimalnya strategi storytelling sebagai strategi story-driven marketing dalam pariwisata, karena tidak semua unsur storytelling muncul dalam unggahan pada akun Instagram objek penelitian. Sebagian besar unggahan pada akun Instagram destinasi wisata Borobudur dan Danau Toba tersebut hanya merujuk pada unsur pesannya saja dan kurang memperhatikan unsur storytelling yang lain. Implikasi dari penelitian ini adalah perlunya berbagai pihak terkait dalam perkembangan pariwisata untuk mengoptimalkan media sosial sebagai sarana promosi, dan meningkatkan strategi storytelling untuk menarik wisatawan.
\end{abstract}

Kata Kunci: Borobudur, Danau Toba, Instagram, pariwisata, storytelling

\title{
Pendahuluan
}

Kementerian Pariwisata menargetkan kunjungan wisatawan mancanegara sebanyak 12 juta orang pada tahun 2016 (Saroh, 2016), kemudian meningkat menjadi 17 juta wisatawan asing yang ditargetkan untuk mengunjungi berbagai destinasi wisata di Indonesia pada tahun 2020 (Safitri, 2020). Banyaknya wisatawan yang berkunjung ke Indonesia tentu menguntungkan karena dapat meningkatkan penerimaan devisa. Sejak tahun 2017 hingga tahun 2020 ini, jumlah devisa yang dihasilkan dari sektor pariwisata berada di peringkat kedua setelah kelapa sawit dan mengalahkan jumlah penerimaan devisa dari minyak bumi dan gas.

Menteri Pariwisata dan Ekonomi Kreatif, Wishnutama, mengatakan bahwa pemerintah menargetkan capaian devisa dari sektor pariwisata tahun 2020 sebesar US\$ 21 juta atau setara dengan Rp 294 miliar (Pratiwi, 2019). Wishnutama yakin besarnya target penerimaan devisa tersebut dapat tercapai, sebab saat ini Indonesia memiliki 5 destinasi super prioritas pariwisata (Pratiwi, 2019), yaitu: (1) Danau Toba di Sumatera Utara, (2) Borobudur di Jawa Tengah, (3) Labuan Bajo di Nusa Tenggara Timur, (4) Mandalika di Nusa Tenggara Barat, (5) Likupang di Sulawesi Utara. Dalam pengembangannya, 5 destinasi super prioritas pariwisata ini menghadapi beberapa kendala, salah satunya adalah belum adanya promosi yang optimal dan komprehensif agar semua pihak mendapatkan multiplier effect yang 
Monika Sri Yuliarti, Andre N. Rahmanto, Anjang Priliantini, Albert Muhammad Isrun Naini, Mahfud Anshori, Christina Tri Hendriyani:

Storytelling of Indonesia Tourism Marketing in Social Media: Study of Borobudur and Danau Toba Instagram Account

Storytelling dalam Pemasaran Pariwisata Indonesia di Media Sosial: Studi Akun Instagram Borobudur dan Danau Toba

besar dan juga berdampak positif bagi pertumbuhan ekonomi daerah (Asmara, 2019).

Komunikasi pemasaran pariwisata Indonesia secara resmi dibentuk oleh Kementerian Pariwisata Republik Indonesia melalui Visit Indonesia Year (VIY) pada tahun 1991, 1992, 2008, 2009, dan 2010 sesuai amanat Undang-undang Pariwisata No. 9 tahun 1990 (Mutma \& Dyanasari, 2018). Seiring dengan perkembangan zaman, pemerintah merasa perlu untuk menggaungkan lagi industri pariwisata Indonesia dengan melakukan branding sebagai teknik komunikasi pemasaran. Salah satunya adalah branding Pesona Indonesia untuk menyasar wisatawan domestik dan Wonderful Indonesia untuk menyasar wisatawan mancanegara pada tahun 2014.

Namun demikian, dengan pandemi COVID-19 yang telah berlangsung sejak awal tahun 2020 ini, maka upaya pemerintah harus semakin besar untuk meningkatkan sektor pariwisata. Bahkan, seperti dilaporkan di laman liputan6.com, Kepala Biro Komunikasi Publik Kementerian Pariwisata dan Ekonomi Kreatif (Kemenparekraf) Agustini Rahayu menyebutkan bahwa kondisi saat ini bagaikan keadaan 20 tahun lalu, mengingat hingga akhir tahun 2020, diprediksi kunjungan wisman hanya mencapai 6 juta orang. Fenomena ini tidak hanya terjadi di Indonesia, tetapi di seluruh dunia, seperti yang dilaporkan oleh UNWT (lembaga PBB bidang pariwisata) yang menyebutkan bahwa pariwisata dunia turun tajam hingga 80\% (Mutiah, 2020).

Meski telah melakukan beberapa teknik komunikasi pemasaran, jumlah kunjungan pariwisata Indonesia pada tahun 2016-2019 selalu meleset dari target yang telah ditetapkan. Karenanya dirasa perlu untuk mengembangkan teknik komunikasi pemasaran yang baru untuk mendongkrak sektor pariwisata. Salah satu yang sedang dikembangkan oleh Kemenpar adalah story-driven marketing yaitu pemasaran berbasis penyebarluasan cerita. Konsep ini dalam ranah pariwisata disebut sebagai tourism storytelling.

Menurut Chusmeru, pengamat pariwisata dari Universitas Jenderal Soedirman, hampir semua daerah di Indonesia memiliki potensi wisata yang menarik, namun belum semua dinarasikan secara baik kepada wisatawan (Ibo, 2019). Padahal menurut Nur Alam dalam Bakti dkk (2019), tujuan dari storytelling adalah membuat suatu daya tarik wisata menjadi semakin menarik dan membuat calon wisatawan penasaran. Oleh karena itu, teknik pemasaran menggunakan tourism storytelling dinilai berpeluang dalam meningkatkan jumlah kunjungan wisatawan dan devisa negara.

Di sisi lain, perkembangan media digital semakin meningkat. Baik di Indonesia maupun di dunia, terjadi peningkatan pengguna internet serta pengguna media sosial. Di awal tahun 2020, We Are Social bekerjasama dengan Hootsuite merilis data pengguna internet dunia yang tercatat mencapai 4,5 miliar. Angka ini meningkat 7\% dibandingkan data Januari 2019. Dari total populasi dunia, 49\% di antaranya merupakan pengguna aktif media sosial, yakni 3,8 miliar. Angka ini meningkat 9\% dari tahun sebelumnya (Kemp, 2020).

Peningkatan pengguna internet juga terjadi di Indonesia. Data We Are Social dan Hootsuite sebagaimana dikutip portal berita online kompas.com (Pertiwi, 2020) menunjukkan bahwa pada awal tahun 2020, lebih dari 175 juta 
penduduk Indonesia merupakan pengguna internet, dengan tingkat penetrasi $64 \%$. Jumlah ini meningkat dari tahun sebelumnya, sekitar 17\% (Pertiwi, 2020). Dari beberapa media sosial yang banyak digunakan tersebut, Instagram menjadi salah satu yang memiliki pengguna cukup banyak, bahkan Indonesia menjadi negara ke4 di dunia dengan pengguna Instagram terbanyak (Hamdan, 2019). Dengan demikian, dapat dikatakan bahwa media sosial dipandang memiliki relevansi yang cukup kuat untuk dijadikan saluran dalam promosi pariwisata.

Lebih lanjut, media sosial semakin banyak digunakan sebagai saluran untuk mengkomunikasikan sesuatu, termasuk pesan-pesan yang berkaitan dengan promosi wisata. Salah satu hal menarik dari pesan di media sosial adalah kemampuannya untuk menjadi viral, di mana word of mouth communication di era internet ini dilakukan dengan saluran media sosial. Pesan yang diciptakan oleh produsen tidak lagi akan menjangkau mereka yang melihat unggahan pesan itu di media sosial tertentu, melainkan juga bisa dibantu dengan fitur berbagi di berbagai platform media sosial, sehingga pengguna media sosial lain bahkan bisa menerima pesan tersebut (Miller \& Lammas, 2010). Hal ini bisa terjadi dalam skala yang besar dan dalam waktu yang sangat cepat. Selain itu, di media sosial, pesan bisa dikemas dengan sedemikian rupa agar bisa dinikmati oleh pera pengguna media sosial, mulai dari gambar hingga video, serta infografik hingga animasi (Huang, Clarke, Heldsinger, \& Tian, 2019).

Beberapa penelitian terkait promosi pariwisata menggunakan media digital telah dilakukan utamanya di beberapa lokasi di Indonesia. Di Jawa Barat misalnya, studi yang dilakukan oleh Novianti dan Wulung (2020) menghasilkan temuan bahwa Pemerintah Jawa Barat menggunakan website, media sosial, serta aplikasi bernama Smiling West Java sebagai usaha dalam mewujudkan Jawa Barat sebagai destinasi pariwisata cerdas, atau smart tourism destination. Lebih lanjut, media digital juga menjadi salah satu solusi dalam diseminasi informasi pariwisata di Provinsi Nusa Tenggara Barat. Penelitian yang dilakukan oleh Setyanto dan Winduwati (2017) menghasilkan temuan bahwa ecotourism dan wisata budaya digunakan sebagai pesan utama untuk menyebarkan informasi pariwisata di wilayah tersebut. Media sosial yang dipandang sesuai adalah YouTube dan website. Sementara itu, secara spesifik, studi tentang digital storytelling juga telah dilakukan oleh beberapa peneliti, salah satunya adalah studi tentang narasi video tourism storytelling berjudul The Journey to A Wonderful World (Trisakti \& Alifahmi, 2018). Selain itu, terdapat juga riset tentang implementasi konsep storytelling melalui pembuatan film pendek bertema wisata (Prasetyo \& Setyadi, 2017). Dari penelusuran terhadap beberapa penelitian terdahulu, dapat diketahui bahwa penelitian terkait tourism storytelling pada media sosial Instagram belum pernah diteliti.

Berdasarkan penjabaran di atas, maka penelitian ini akan mengeksplorasi digital storytelling dalam dua destinasi wisata yang masuk dalam kategori 5 destinasi super prioritas pariwisata, yaitu Borobudur di Jawa Tengah dan Danau Toba di Sumatera Selatan, dengan melihat Instagram mereka. Dua destinasi ini dipilih dengan pertimbangan salah satu berada di pulau Jawa, dan destinasi lain berada di luar pulau Jawa, di mana diharapkan dengan representasi pulau Jawa dan luar Jawa ini bisa memberikan gambaran yang lebih umum. 
Monika Sri Yuliarti, Andre N. Rahmanto, Anjang Priliantini, Albert Muhammad Isrun Naini, Mahfud Anshori, Christina Tri Hendriyani:

Storytelling of Indonesia Tourism Marketing in Social Media: Study of Borobudur and Danau Toba Instagram Account

Storytelling dalam Pemasaran Pariwisata Indonesia di Media Sosial: Studi Akun Instagram Borobudur dan Danau Toba

\section{Metode Penelitian}

Penelitian ini akan mengeksplorasi data dan informasi terkait narasi atau cerita yang telah dikonstruksi atau berkembang pada objek penelitian, yaitu Borobudur di Jawa Tengah dan Danau Toba di Sumatera Utara. Untuk mengeksplorasi konsep tourism storytelling, penelitian ini menggunakan metode analisis isi deskriptif kuantitatif agar menghasilkan data yang objektif dan sistematis. Menurut Krippendorf (2004), tujuan analisis konten adalah memberikan pengetahuan, wawasan baru, representasi fakta, dan panduan praktis untuk bertindak.

Data yang digunakan dalam penelitian ini terbagi atas data primer dan data sekunder. Data primer yang digunakan dalam penelitian ini adalah akun Instagram dari masing-masing objek wisata prioritas Indonesia. Secara spesifik, data primer dalam penelitian ini adalah akun Instagram @borobudurpark dan @danau_tobasamosir. Lebih lanjut, data sekunder dalam penelitian ini adalah buku, artikel berita, artikel jurnal, dan beberapa referensi lain yang sesuai dengan topik penelitian ini.

Unit analisis dalam penelitian ini adalah foto, video, serta kata-kata yang terdapat dalam caption pada setiap unggahan dari objek penelitian ini. Sementara itu, teknik pengumpulan data penelitian dilakukan dengan menggunakan metode studi dokumen atau studi literatur. Dalam metode ini, sumber datanya tertulis, baik dalam bentuk cetak maupun daring (Bungin, 2008). Dalam prakteknya, peneliti memilih akun Instagram objek wisata yang akan diteliti, yaitu @ borobudurpark dan @danau_tobasamosir dan mencari informasi yang berkaitan dengan masalah penelitian. Periode yang ditetapkan dalam penelitian ini adalah bulan Juli 2020. Penentuan periode ini didasarkan pada bulan liburan serta beberapa tempat wisata telah mulai membuka kembali destinasi pariwisata di masa pandemi dengan protokol kesehatan, setelah sebelumnya ditutup total. Selama satu bulan tersebut, diketahui bahwa akun @borobudurpark selama periode bulan Juli 2020 hanya mengunggah dua konten yang terdiri dari satu video dan satu foto. Sedangkan akun @ danau_tobasamosir menggunggah sejumlah 37 konten, di mana 12 di antaranya berupa video, dan sisanya adalah foto. Semua unggahan pada kedua akun Instagram tersebut selanjutnya dilakukan proses pengkodingan secara manual oleh dua pengkoder.

Saat menganalisis data, peneliti menghimpun dan mengkategorisasikan data yang ditemukan berdasarkan unit-unit analisis dan informasi umum seperti gambar (foto atau video), jumlah likes, caption, dan komentar. Adapun unit-unit analisis diturunkan dari konsep tourism dan storytelling. Unit analisis aspek tourism merujuk pada UU No. 10 tahun 2009 tentang Kepariwisataan (Pemerintah Indonesia, 2009), yaitu (1) Atraksi, merupakan daya tarik berupa alam, budaya, objek wisata buatan, event, dan tata ruang; (2) Amenitas, merupakan fasilitas dasar yang memberi kenyamanan dan keamanan bagi wisatawan, serta (3) Aksesibilitas, merupakan ketersediaan sarana yang memberikan kemudahan untuk menjangkau destinasi wisata. 
Sedangkan unit analisis aspek storytelling menggunakan gagasan dari Fog dkk. (2010) dan Gitner (2016), yaitu (1) Setting, gambaran tempat dan waktu pengambilan cerita; (2) Karakter, gambaran orang atau tokoh yang muncul beserta perannya dalam cerita; (3) Konflik, menggambarkan keadaan di lokasi yang terkadang tidak sesuai dengan ekspektasi dan bagaimana karakter tersebut mengatasi situasi tersebut; (4) Plot, merupakan alur penyajian cerita; dan (5) Pesan, merupakan pernyataan moral atau premis (kesimpulan) yang dapat diambil dari cerita. Hasil dari kategorisasi ini dapat memudahkan peneliti dalam melihat pola dan menarik kesimpulan atas penerapan konsep tourism storytelling dalam setiap unggahan yang ada dalam akun Instagram objek wisata Borobudur (@borobudurpark)dan Danau Toba (@danau_tobasamosir).

Untuk menghindari bias dan subjektivitas, dilakukan uji keabsahan data dengan melibatkan dua pengkoder. Sebelum melakukan observasi, kedua pengkoder telah memiliki pemahaman yang sama terkait unit-unit yang diteliti. Lebih lanjut, kedua pengkoder juga saling bertukar objek yang diobservasi untuk memastikan hasil analisis tidak timpang.

\section{Hasil Penemuan dan Diskusi}

Berdasarkan proses pengumpulan data terhadap objek penelitian, diketahui bahwa akun @borobudurpark selama periode bulan Juli 2020 hanya mengunggah dua konten yang terdiri dari satu video dan satu foto. Hal ini sangat berbeda jika dibandingkan dengan akun @danau_tobasamosir yang selama bulan Juli 2020 menggunggah sejumlah 37 konten, di mana 12 di antaranya berupa video, dan sisanya adalah foto, yaitu sejumlah 25 buah. Data ini menunjukkan bahwa akun @ danau_tobasamosir memiliki kemungkinan online engagement yang lebih besar dengan para pengikut (follower) nya. Hal ini sesuai dengan studi yang dilakukan oleh Santoso, dkk. (2017) yang menemukan bahwa frekuensi unggahan di media sosial bisa meningkatkan online engagement dengan pengikut di media sosial tersebut yang juga merupakan konsumen maupun konsumen potensial.

Hal tersebut semakin ditunjukkan dengan jumlah likes yang didapatkan oleh kedua akun Instagram tersebut. Dari unggahan-unggahan di kedua akun Instagram tersebut, like terbanyak yang didapatkan oleh akun@danau_tobasamosir adalah sebanyak 513 likes. Di sisi lain, akun @ borobudurpark pada unggahan fotonya mendapatkan like hanya sebanyak 106 likes. Dalam artikel Santoso dkk. (2017) juga disebutkan bahwa online engagement bisa diketahui dari like dan komentar yang diberikan oleh para pengikut pada unggahan pada akun media sosial.

\section{Unsur-Unsur Pariwisata: Atraksi, Amenitas, Aksesibilitas}

Berkaitan dengan unsur-unsur pariwisata yang dalam penelitian ini didasarkan pada UU No. 10 tahun 2009 tentang Kepariwisataan (Pemerintah Indonesia, 2009), didapati ada tiga unsur, yaitu atraksi, amenitas, dan aksesibilitas. Dalam tabel 1 tampak bahwa unsur atraksi mendominasi akun @ danau_tobasamosir, yaitu sebesar 96.9\%. Secara spesifik, dalam unsur itu tercatat beberapa detail yaitu pemandangan, makanan khas, rumah adat, dan lagu daerah. Dari keempat detail tersebut, pemandangan sangat mendominasi unsur atraksi. Hal 
Monika Sri Yuliarti, Andre N. Rahmanto, Anjang Priliantini, Albert Muhammad Isrun Naini, Mahfud Anshori, Christina Tri Hendriyani:

Storytelling of Indonesia Tourism Marketing in Social Media: Study of Borobudur and Danau Toba Instagram Account

Storytelling dalam Pemasaran Pariwisata Indonesia di Media Sosial: Studi Akun Instagram Borobudur dan Danau Toba

ini sejalan dengan jenis pariwisata dari Danau Toba itu sendiri yang merupakan objek wisata alam, sehingga konten yang menampilkan daya tarik berupa pemandangan alam, di antaranya adalah pemandangan danau itu sendiri, serta keindahan bukit di sekitar danau. Pada akun @borobudurpark unsur atraksi hanya muncul dalam satu unggahan saja atau sebesar $3.1 \%$ dan menampakkan pemandangan juga, walaupun tidak mendominasi. Hal ini disebabkan karena Borobudur adalah wisata candi, maka tampilan candi lebih mendominasi dibandingkan dengan pemandangan. Hal ini sejalan dengan studi yang dilakukan oleh Khotimah dkk. (2017) terkait dengan strategi pengembangan destinasi pariwisata pada situs Trowulan. Dalam studinya tersebut ditemukan bahwa atraksi merupakan sebuah kekuatan bagi objek wisata, di mana perlu untuk menciptakan atraksi yang mampu dilihat, dikerjakan, dan dibeli. Dalam konteks pemandangan sebagai atraksi tersebut adalah perwujudan dari atraksi yang mampu dilihat dalam lingkup yang lebih luas. Sehingga, tidak hanya objeknya saja yang perlu diberi perhatian khusus, melainkan juga wilayah yang jangkauannya lebih luas, dalam hal ini adalah pemandangan sekitar.

Tabel 1. Rekap Koding Data Unsur Pariwisata akun Instagram @borobudurpark dan@danau_tobasamosir periode bulan Juli 2020

\begin{tabular}{llccc}
\hline No. & Objek Penelitian & \multicolumn{3}{c}{ Unsur pariwisata } \\
\cline { 3 - 5 } & & atraksi & amenitas & aksesibilitas \\
1. & @borobudurpark & $3.1 \%$ & $33.3 \%$ & $28.6 \%$ \\
2. & @danau_tobasamosir & $96.9 \%$ & $66.7 \%$ & $71.4 \%$
\end{tabular}

Sangat berbeda dengan unsur atraksi, unsur amenitas dan aksesibilitas sangat tidak mendominasi dari unggahan kedua akun Instagram yang menjadi objek penelitian ini. Jika diamati dari tabel 1, unsur amenitas muncul di salah satu unggahan akun@borobudurpark selama periode penelitian. Secara lebih detail, unsur ini ditunjukkan dalam video yang menampilkan toko kerajinan dan souvenir yang berada di sekitar wilayah Candi Borobudur. Sementara itu, pada akun @danau_tobasamosir, unsur amenitas ini paling tidak dominan di antara ketiga unsur lain, karena hanya muncul di dua unggahan saja, yang secara detail ditunjukkan dalam foto tempat duduk. Selain tempat duduk yang nyaman dan toko souvenir, sesunguhnya banyak unsur amenitas lain yang bisa ditampilkan juga dalam unggahan akun Instagram untuk meningkatkan promosi pariwisata. Nabila dan Widiyastuti (2018) setidaknya menemukan 16 amenitas saat melakukan studi terhadap Umbul Ponggok, di antara: rumah makan, toilet, rest area, pos pertolongan pertama, mushola, fotografi, security, loket/ ticketing, panggung, penginapan, swalayan, masjid, dan ATM Center

Terakhir, yaitu unsur aksesibilitas. Dari tabel 1 tampak bahwa pada akun @ borobudurpark, terdapat 2 unggahan yang mengandung unsur aksesibilitas atau sebesar $28.6 \%$, di mana unsur ini muncul pada video dan pada komentar. Secara spesifik, aksesibilitas di sini yang dimaksud adalah informasi terkait tiket serta syarat dalam mengunjungi Candi Borobudur, serta perlu tidaknya menunjukkan hasil rapid test saat akan berkunjung ke Candi Borobudur, mengingat bulan Juli 
2020 ini masih masa pandemi COVID-19. Informasi ini sangat penting diketahui untuk calon pengunjung karena selama masa pandemi COVID-19, banyak tempat umum termasuk kawasan wisata yang ditutup. Sementara itu, untuk akun @ danau_tobasamosir, unsur aksesibilitas hanya muncul pada lima unggahan atau sebesar $71.4 \%$, dan hanya didominasi oleh jalur fisik untuk masuk ke dalam kawasan Danau Toba. Secara detil, yang ditampakkan adalah berupa jalan yang halus dan jalan yang sempit, yang keduanya ditampilkan dalam unggahan yang berbentu foto serta video. Selain terkait dengan infrastruktur berupa akses masuk serta ticketing dan persyaratan untuk bisa mengunjungi lokasi wisata tertentu, aksesibilitas juga bisa didukung dengan adanya bandara, terminal, atau stasiun di dekat lokasi (Khotimah, Wilopo, \& Hakim, 2017), sehingga sesungguhnya hal-hal tersebut juga sangat mungkin untuk dimunculkan dalam konten unggahan pada kedua akun Instagram objek penelitian.

\section{Unsur Storytelling: Setting, Karakter, Konflik, Plot, Pesan}

Beralih kepada unsur storytelling, di mana dalam penelitian ini unsur yang dilihat adalah setting, karakter, konflik, plot, dan pesan, berdasarkan konsep dari Fog dkk. (2010) dan Gitner (2016). Kelima pesan ini merupakan sebuah kesatuan yang jika salah satu unsur saja tidak terdapat, tentu storytelling tidak akan bisa tersampaikan dengan sempurna. Dari data yang terdapat pada tabel 2 bisa diketahui bahwa baik akun@borobudurpark maupun akun@danau_tobasamosir dalam unggahannya, unsur storytelling sama-sama tidak semuanya muncul, yaitu unsur konflik. Padahal di sisi lain, konflik merupakan sebuah unsur yang sangat penting dalam sebuah storytelling. Harmon dan Holman dalam Donly (Donly, 2017) menyebutkan bahwa konflik adalah sebuah unsur yang memiliki peran penting dalam mendukung plot dalam storytelling. Sehingga, keberadaan konflik menjadi sebuah keharusan, karena tanpanya, plot tidak akan bisa tercipta.

Tabel 2. Rekap Koding Data Aspek Storytelling pada akun Instagram @ borobudurpark dan @ danau_tobasamosir periode bulan Juli 2020

\begin{tabular}{llccccc}
\hline No. & Objek Penelitian & \multicolumn{5}{c}{ Unsur-Unsur Storytelling } \\
\cline { 3 - 6 } & & Setting & Karakter & Konflik & Plot & Pesan \\
1. & @borobudurpark & $3.4 \%$ & $11.1 \%$ & - & $33.3 \%$ & $5.1 \%$ \\
2. & @danau_tobasamosir & $96.6 \%$ & $88.9 \%$ & - & $66.7 \%$ & $94.9 \%$ \\
\hline
\end{tabular}

Dari tabel 2 bisa pula diketahui bahwa unsur pesan paling mendominasi di antara unsur-unsur lainnya utamanya di akun@danau_tobasamosir (sebanyak 37 unggahan, atau 94.9\%). Hal ini terjadi karena pesan dalam storytelling memiliki kekuatan unik untuk menyampaikan sesuatu kepada audiens. Terlebih jika pesan ini dibungkus dengan menggunakan visual yang menarik berupa foto maupun video, tentu akan membuat audiens memberikan perhatian lebih. Hal ini sejalan dengan hasil penelitian (2008) yang menunjukkan bahwa pesan tentang nilai-nilai serta produk sebuah perusahaan bisa diterima di kalangan audiens, karena pengemasan pesan yang mampu memunculkan unsur emosi dan keterikatan di kalangan audiens terhadap perusahaan. Dalam konteks penelitian ini, pesan yang 
Monika Sri Yuliarti, Andre N. Rahmanto, Anjang Priliantini, Albert Muhammad Isrun Naini, Mahfud Anshori, Christina Tri Hendriyani:

Storytelling of Indonesia Tourism Marketing in Social Media: Study of Borobudur and Danau Toba Instagram Account

Storytelling dalam Pemasaran Pariwisata Indonesia di Media Sosial: Studi Akun Instagram Borobudur dan Danau Toba

mendominasi adalah terkait dengan keindahahan alam serta keindahan destinasi wisata secara umum, baik yang berkaitan dengan objek wisatanya itu sendiri maupun hal lain yang secara tidak langsung terhubung, namun masih dalam kemasan adat istiadat.

Selanjutnya, unsur karakter dan plot ini hanya muncul sedikit dalam unggahan-unggahan pada akun Instagram @borobudurpark maupun akun @danau_tobasamosir.Pada akun @danau_tobasamosir, karakter yang nampak bisa dilihat dari unggahan-unggahan berupa foto yang selain secara dominan menampilkan keindahan pemandangan alam, juga terdapat karakter manusia yang digambarkan dengan berbagai cara, misalnya dengan ekspresi wajah, pose, maupun kostum yang dikenakan. Secara umum, masing-masing foto didominasi oleh satu orang saja, sehingga kaakter yang terbentuk juga hanya satu untuk masing-masing unggahan. Selain melalui foto, unsur karakter pada unggahan akun @ danau_tobasamosir juga ditampilkan dalam video yang menampilkan keceriaan sekelompok anak muda yang sedang berwisata ke destinasi wisata tersebut. Karakter juga bisa diamati dari ekspresi wajah dan kostum. Namun, karena video dan foto memiliki perbedaan karakter sajian, maka dalam video bukan pose yang digunakan sebagai dasar untuk melihat karakter, melainkan pergerakan badan orang-orang yang terdapat dalam foto tersebut.

\section{Simpulan}

Berdasarkan analisis yang telah dilakukan, kesimpulan dari penelitian ini adalah belum optimalnya digital storytelling yang dilakukan oleh destinasi wisata Indonesia, dalam hal ini Candi Borobudur dan Danau Toba melalui media sosial Instagram, baik melalui unggahan berupa foto maupun video, caption, serta komentar. Hal ini bisa diketahui karena tidak semua unsur storytelling muncul dalam unggahan akun Instagram kedua destinasi wisata tersebut, sehingga unsurunsur pariwisata yang ada juga belum secara optimal terpromosikan dengan melalui storytelling.

Mengingat media sosial Instagram semakin meningkat perkembangannya dan strategi storytelling memiliki kekuatan dalam menarik minat masyarakat, diharapkan para pihak yang memiliki keterkaitan dengan destinasi wisata, baik pemerintah maupun swasta mulai memanfaatkan strategi ini untuk menarik wisatawan. Penelitian ini adalah awal untuk eksplorasi lebih mendalam terkait destinasi wisata lain, sehingga diharapkan bisa menjadi referensi bagi studi lain yang bisa menggunakan objek penelitian platform media sosial yang lain atau website. Selain itu, kajian mendatang terkait dengan hal ini bisa juga diaplikasikan pada periode yang lebih panjang.

\section{Ucapan Terima Kasih}

Artikel ini merupakan luaran dari penelitian skim Hibah Research Group dari dana PNBP UNS 2020 


\section{Daftar Pustaka}

Asmara, C. G. (2019, Juli 15). Pengembangan 10 "Bali Baru”, Jokowi Sebut 6 Kendala Utama. Retrieved Februari 5, 2020, from cnbcindonesia.com: https://www.cnbcindonesia.com/news/20190715181647-485111/pengembangan-10-bali-baru-jokowi-sebut-6-kendala-utama

Bakti, I., Sumartias, S., Damayanti, T., \& Nugraha, A. R. (2019). Pelatihan Storytelling dalam Membangun Ekonomi Kreatif Bidang Pariwisata di Desa Cintaratu Kecamatan Parigi Kabupaten Pangandaran. Jurnal Bakti Masyarakat Indonesia, 1(1), 25-31.

Bungin, M. B. (2008). Penelitian Kualitatif; Komunikasi, Ekonomi, Kebijakan Publik, dan Ilmu Sosial Lainnya. Jakarta: Kencana.

Donly, C. (2017). Toward the Eco-Narrative: Rethinking the Role of Conflict in Storytelling. Humanities, 6(17), 1-22.

Fog, K., Budtz, C., Munch, P., \& Blanchette, S. (2010). Storytelling: Branding in Practice. Heidelberg: Springer-Verlag Berlin.

Gitner, S. (2016). Multimedia Storytelling for Digital Communicators in a Multiplatform World. New York: Routledge.

Hamdan, N. (2019, Desember 28). Pengguna Instagram di Indonesia Terbesar ke4 Dunia. Retrieved Agustus 15, 2020, from Tagar.id: https://www.tagar.id/pengguna-instagram-di-indonesia-terbesar-ke4dunia

Hermansson, E. (2008). How does company communicate through storytelling? Kristianstad, Swedia: Kristianstad University.

Huang, L., Clarke, A., Heldsinger, N., \& Tian, W. (2019). The communication role of social media in social marketing: a study of the community sustainability knowledge dissemination on LinkedIn and Twitter. Journal of Marketing Analytics, 7, 64-75.

Ibo, A. (2019, Agustus 26). Storynomic Tourism, Cara Menjual Wisata Daerah dengan Cerita. Retrieved Agustus 15, 2020, from liputan6.com: https://www.liputan6.com/regional/read/4046860/storynomic-tourismcara-menjual-wisata-daerah-dengan-cerita

Kemp, S. (2020, January 31). Digital 2020: 3.8 Billion People Use Social Media. Retrieved August 25, 2020, from We Are Social: https://wearesocial.com/blog/2020/01/digital-2020-3-8-billion-peopleuse-socialmedia\#: :text=Our\%20new\%20Digital\%202020\%20reports,passed\%20t he\%203.8\%20billion\%20mark.

Khotimah, K., Wilopo, \& Hakim, L. (2017). STRATEGI PENGEMBANGAN DESTINASI PARIWISATA BUDAYA (Studi Kasus pada Kawasan Situs Trowulan sebagai Pariwisata Budaya Unggulan di. Jurnal Administrasi Bisnis (JAB), 4l(1), 56-65.

Krippendorf, K. (2004). Content Analysis: Introduction to its methodology (Vol. 2nd). California: Sage Publication.

Miller, R., \& Lammas, N. (2010). Social media and its implications for viral marketing. Asia Pacific Public Relations Journal, 1, 1-10. 
Monika Sri Yuliarti, Andre N. Rahmanto, Anjang Priliantini, Albert Muhammad Isrun Naini, Mahfud Anshori, Christina Tri Hendriyani:

Storytelling of Indonesia Tourism Marketing in Social Media: Study of Borobudur and Danau Toba Instagram Account

Storytelling dalam Pemasaran Pariwisata Indonesia di Media Sosial: Studi Akun Instagram Borobudur dan Danau Toba

Mutiah, D. (2020, Desember 14). Pandemi Covid-19 Pukul Mundur Sektor Pariwisata Indonesia ke 20 Tahun Lalu. Retrieved Februari 1, 2021, from www.liputan6.com:

https://www.liputan6.com/lifestyle/read/4432545/pandemi-covid-19pukul-mundur-sektor-pariwisata-indonesia-ke-20-tahun-lalu

Mutma, F. S., \& Dyanasari, R. (2018). Perencanaan Komunikasi Pemasaran Wonderful Indonesia sebagai Place Branding Indonesia. Communicare: Journal of Communication Studies, 5(2), 61-80.

Nabila, A. D., \& Widiyastuti, D. (2018). Kajian Atraksi, Amenitas dan Aksesibilitas untuk Pengembangan Pariwisata Umbul Ponggok di Kabupaten Klaten. Jurnal Bumi Indonesia, 7(3), 1-8.

Novianti, E., \& Wulung, S. R. (2020). Implementasi Komunikasi Daring dalam Menunjang Jawa Barat sebagai Destinasi Pariwisata Cerdas. Jurnal Komunikasi, 12(1), 53-63.

Pemerintah Indonesia. (2009). Undang-Undang Republik Indonesia Nomor 10 Tahun 2009 tentang Kepariwisataan. Jakarta: Sekretariat Negara.

Pertiwi, W. K. (2020, February 20). Penetrasi Internet di Indonesia Capai 64 Persen. Retrieved August 25, 2020, from Kompas.Com: https://tekno.kompas.com/read/2020/02/20/14090017/penetrasi-internetdi-indonesia-capai-64-persen

Prasetyo, D., \& Setyadi, D. I. (2017). Perancangan Film Pendek Bertema Wisata Dengan Pendekatan Storytelling Sebagai Media Promosi Wisata Pulau Bawean. Jurnal Sains dan Seni ITS, 6(1), 1-13.

Pratiwi, I. (2019, Desember 25). Menpar Bidik Devisa Pariwisata Rp 294 miliar pada 2020. Retrieved Februari 5, 2020, from Republika.com: https://republika.co.id/berita/q32dmd383/menpar-bidik-devisapariwisata-rp-294-miliar-pada-2020

Safitri, K. (2020, Januari 16). Kemenpar Targetkan 17 Juta Wisman Kunjungi RI pada 2020. Retrieved Februari 5, 2020, from kompas.com: https://money.kompas.com/read/2020/01/16/172506426/kemenpartargetkan-17-juta-wisman-kunjungi-ri-pada-2020

Santoso, A. P., Baihaqi, I., \& Persada , S. (2017). Pengaruh Konten Post Instagram terhadap Online Engagement: Studi Kasus pada Lima Merek Pakaian Wanita. Jurnal Teknik ITS, 6(1), 217-221.

Saroh, M. (2016, September 16). Tahun 2016, Kemenpar Menarget 12 Juta Wisman ke Indonesia. Retrieved Februari 5, 2020, from tirto.id: https://tirto.id/tahun-2016-kemenpar-menarget-12-juta-wisman-keindonesia-bKS8

Setyanto, Y., \& Winduwati, S. (2017). Diseminasi Informasi Terkait Pariwisata Berwawasan Lingkungan dan Budaya Guna Meningkatkan Daya Tarik Wisatawan (Studi pada Dinas Pariwisata Provinsi Nusa Tenggara Barat). Jurnal Komunikasi, 9(2), 164-175.

Trisakti, F. A., \& Alifahmi, H. (2018). Destination Brand Storytelling: Analisis Naratif Video The Journey to A Wonderful World Kementerian Pariwisata. Jurnal Komunikasi Indonesia, 7(1), 73-86. 